\title{
Feedback mechanisms in coagulation
}

Citation for published version (APA):

Hemker, H. C., \& Kessels, H. (1991). Feedback mechanisms in coagulation. Haemostasis, 21(4), 189196. https://doi.org/10.1159/000216228

Document status and date:

Published: 01/01/1991

DOI:

10.1159/000216228

Document Version:

Publisher's PDF, also known as Version of record

\section{Please check the document version of this publication:}

- A submitted manuscript is the version of the article upon submission and before peer-review. There can be important differences between the submitted version and the official published version of record.

People interested in the research are advised to contact the author for the final version of the publication, or visit the DOI to the publisher's website.

- The final author version and the galley proof are versions of the publication after peer review.

- The final published version features the final layout of the paper including the volume, issue and page numbers.

Link to publication

\footnotetext{
General rights rights.

- You may freely distribute the URL identifying the publication in the public portal. please follow below link for the End User Agreement:

www.umlib.nl/taverne-license

Take down policy

If you believe that this document breaches copyright please contact us at:

repository@maastrichtuniversity.nl

providing details and we will investigate your claim.
}

Copyright and moral rights for the publications made accessible in the public portal are retained by the authors and/or other copyright owners and it is a condition of accessing publications that users recognise and abide by the legal requirements associated with these

- Users may download and print one copy of any publication from the public portal for the purpose of private study or research.

- You may not further distribute the material or use it for any profit-making activity or commercial gain

If the publication is distributed under the terms of Article $25 \mathrm{fa}$ of the Dutch Copyright Act, indicated by the "Taverne" license above, 


\title{
Feedback Mechanisms in Coagulation
}

\author{
H.C. Hemker, H. Kessels \\ Cardiovascular Research Institute Maastricht, Department of Biochemistry, Rijksuniversiteit Limburg, \\ Maastricht, The Netherlands
}

Key Words. Blood coagulation · Feedback

It is one of the main charms of blood coagulation that advanced biochemistry is continuous to everyday medical practice and vice versa. Common clinical facts hide the most enchanting enzymology. The prothrombin time (PT, thromboplastin time, Quick time) and the activated partial thromboplastin time (APTT) are perfect examples. Both are commonly used in the clinical laboratory as global tests for the function of the coagulation system and for the control of anticoagulant therapy. They are at the basis of the classical one-stage clotting factor determinations. Practice has taught us that the PT is perfectly suited for the control of anticoagulant therapy but not for measuring the effect of heparin, whereas the APTT can serve both purposes. Only recently was it found out why: the length of the APTT is primarily determinated by the time necessary for the activation of factor VIII by thrombin [1]. Now thrombin, of course, is the final enzyme of the coagulation cascade, whereas factor VIII is one of the factors necessary for its formation. The product activates one of the proteins instrumental in its own formation: a clearcut case of feedback activation. Obviously, if thrombin is quickly inactivated, as in the presence of heparin, the activation of factor VIII will take longer and the APTT will be prolonged. But one answer immediately engenders a number of questions: How does the first molecule of thrombin arise without the help of any activated factor VIII?, is there another way to activate factor VIII?, is factor VIIIa not absolutely necessary for thrombin formation in the APTT? And again: If the feedback effect shows up so readily with factor VIII in the intrinsic system, why don't we see it in the supposedly completely analogous situation with factor $\mathrm{V}$, either intrinsically or extrinsically?

Thus, from a simple observation in the clinical laboratory one lands in a tangle of biochemical questions of the most interesting kind.

In the present issue, several articles are devoted to the discussion of feedback mechanisms in coagulation. The manuscripts were based upon the presentations of the authors at a symposium during the 21 st Meeting of the Federation of the European Biochemical Societies organised by Prof. Elödi Susan and the present author $(\mathrm{HCH})$. The reader will see how they span a wide 
range of interest, from fundamental to clinical. As a prelude to the more specialized articles that follow, we start with a short introduction to the feedback reactions of coagulation as we understand them now.

\section{The Mechanism of Thrombin Formation}

It is impossible to discuss feedback reactions in coagulation without first giving a general outline of the biochemical mechanism that leads to thrombin formation. Proenzyme to enzyme conversions form the backbone of this mechanism. As early as 1894, Pekelharing [2] published experiments in which he isolated a prothrombin-containing fraction free of fibrinogen and fibrinogen free of prothrombin. He observed that a tissue extract would form thrombin in his prothrombin preparation and drew the correct conclusion that he had isolated the proenzyme of the clotting enzyme. Incidentally, this is to our knowledge even the first time that a proenzyme was isolated and explicitly recognized. Clotting was recognized in 1963 to consist of a series of proenzyme to enzyme conversions [3, 4]. At that time it was thought that all clotting factors were proenzymes which were converted into enzymes in a strict sequential order: the clotting cascade. Now we know that only the vitamin-Kdependent clotting factors II (prothrombin), VII, IX and $X$ are the proenzymes. The sequence of activation is either VII $\rightarrow \mathrm{X} \rightarrow$ II or, alternatively VII $\rightarrow$ IX $\rightarrow \mathrm{X} \rightarrow$ II (fig. 1). Each of these activations takes place at a phospholipid surface in the presence of an accelerating helper protein, which is also adsorbed onto that surface (fig. 2). These helper proteins may conveniently be called paraenzymes. We prefer this term to the more commonly used 'protein cofactor' because in general enzymology is by definition a second substrate (e.g. NADH), and thus suggests a mechanism that is quite different from what actually happens. The complete enzyme complex thus consists of the actual enzyme, that carries the active site (VII, IX or X), the paraenzyme [tissue factor (-thromboplastin), VIIIa or Va] and the procoagulant phospholipid on which both are adsorbed. In order to be an efficient procoagulant surface, the phospholipid has to be negatively charged. For all practical purposes, it has to contain phosphatidylserine.

In terms of enzyme kinetics, the phospholipid decreases the $K_{m}$ of the reaction and the paraenzyme increases the $\mathbf{k}_{\text {cat }}$. This means that, in the presence of a procoagulant phospholipid surface, the enzyme is easily saturated at normal plasma concentrations of the substrate, whereas it is far from saturated in free solution. The effect on $\mathrm{k}_{\text {cat }}$ means that the presence of the paraenzyme increases the number of substrate molecules that one molecule of enzyme per unit time about one thousandfold. In terms of physiology, the phospholipid localizes the reaction at the site of a lesion in the vessel (any wound, but also e.g. an atheromatous lesion) and the paraenzyme serves to regulate the velocity of the reaction. The positive and negative feedback reactions of coagulation play their role primarily via activation and inactivation of the paraenzymes.

\section{Positive and Negative Feedback in the Activation of Factor $\mathrm{X}$}

Coagulation starts because factor VII combines with tissue factor, an integral membrane protein that occurs in cells sur- 


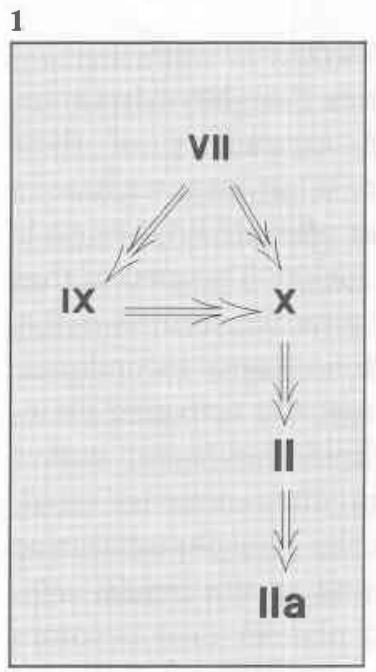

2

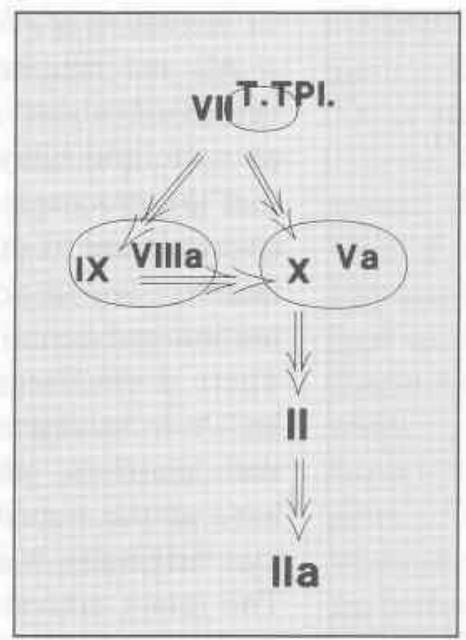

3

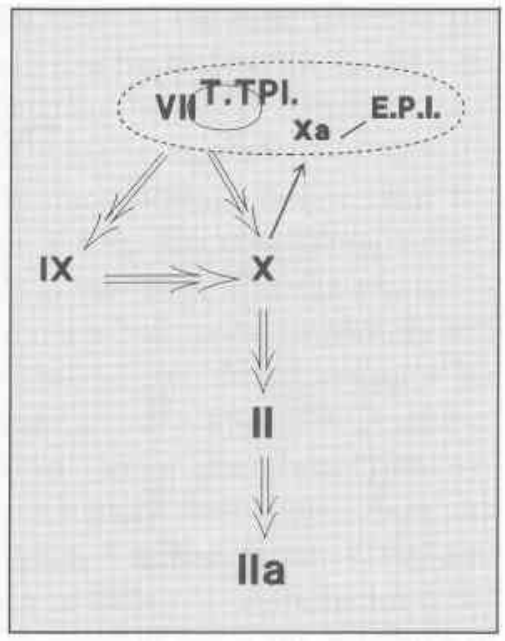

Fig. 1. The proenzyme to enzyme conversions in thrombin generation.

Fig. 2. The paraenzymes and phospholipids in thrombin generation.

Fig. 3. The negative feedback in factor $X$ activation.

Table 1. The phospholipid-bound complexes of the clotting system

\begin{tabular}{lllll}
\hline Enzyme & Paraenzyme & Substrate & Activator & Inactivator \\
\hline VII(a) & TPL & X,IX & Xa & EPI-Xa \\
IXa & VIIIa & X & IIa & APC \\
Xa & Va & II & IIa & APC \\
IIa & Thr.mod & Prot.C & - & - \\
APC & (prot.S?) & Va,VIIIa & - & - \\
\hline
\end{tabular}

rounding the blood vessels and in the skin. In contrast to the other activation steps, here the phospholipid and the paraenzyme are always tightly bound together. Even though factor VII is not activated it shows already a certain, low activity when complexed to thromboplastin [see ref. 5 for further discussion and references]. It therefore can activate some factor X. Factor Xa, in a first positive feedback reaction then activates factor VII, which now becomes $10-100$ times as active and starts to activate factor $\mathrm{Xa}$ at a high velocity. Factor $\mathrm{Xa}$ in plasma finds the $e x$ trinsic pathway inhibitor (EPI) [6, 7]. The factor Xa-EPI complex is a very efficient inhibitor of the factor VIIa-thromboplastin complex. This is the negative feedback in factor X activation (fig. 3). The presence of factor Xa produces an inhibitor of the factor $\mathrm{X}$-activating enzyme. The result is a sudden wave of factor Xa generation. A comparable mechanism acts on factor IX. After the acti- 


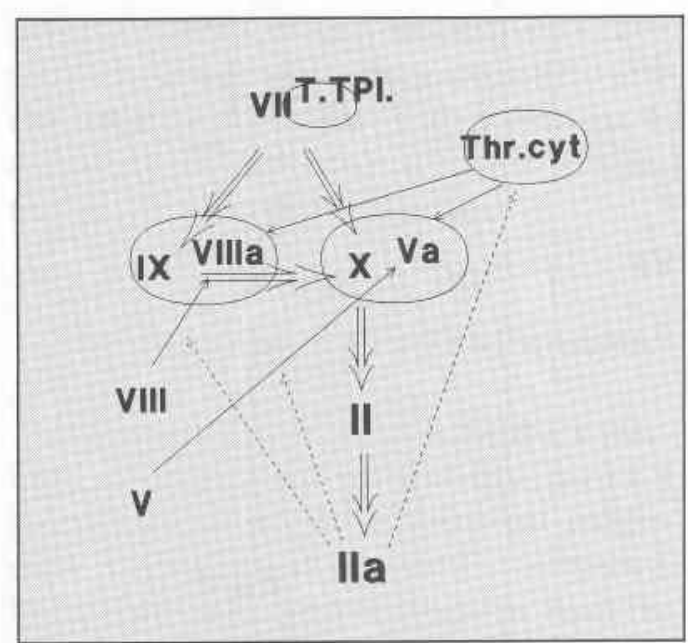
bin.

Fig. 4. The positive feedback effects of throm-

vation wave is over, the only way to form more factor $\mathrm{Xa}$ is via the factor IXa-factor VIIIa-phospholipid complex. This may explain why hemophiliacs usually bleed in thromboplastin-poor organs like muscles and joints, rather than in thromboplastin rich organs like brain and lung. The quantitative kinetics of factor $\mathrm{Xa}$ activation in plasma still have to be determined. Preliminary results suggest that the pulse duration is always 1-2 min and that the height of the pulse is determined by the amount of thromboplastin, but not linearly [8].

\section{The Thrombin-Dependent Positive Feedbacks}

Thrombin has three positive feedback effects on its own formation: (a) The activation of platelets, (b) the activation of factor VIII and (c) the activation of factor V (fig. 4).

\section{Activation of Platelets}

All cell membranes that have been investigated show an asymmetry of their phospholipid bilayer. What imports here is that the procoagulant phosphatidylserine is always found at the inside. This makes that intact cells will not provoke thrombin formation and hence do not cause thrombosis. There is one exception: the activated platelet. A transbilayer lipid movement makes that platelets, when they are activated, have at the outside the phosphatidylserine that originally is found at the inside only. The intact activated platelet thus becomes procoagulant [9]. Two physiological platelet activators produce this phenomenon: collagen and thrombin. In combination, they are even more active than the sum of their individual actions. The relative importance of the activators is dependent upon the platelet concentration. At $10^{6}$ platelets $/ \mathrm{ml}$, collagen is more potent than thrombin, but at the normal concentration $\left(10^{8}\right.$ platelets/ml plasma), thrombin is perfectly effective at a concentration as low as $10 \mathrm{n} M$ $(0.05 \%$ of the plasma prothrombin concentration), and collagen has no additional effect [10].

It is easy to imagine a physiological scenario that shows the importance of these observations. As soon as a wound occurs the platelets gain access to the perivascular connective tissue, adhere to the connective tissue matrix (collagen, etc.) and produce phosphatidylserine at their outside surface. This phosphatidylserine fosters thrombin formation and by this thrombin more platelets will become activated, aggregating to those already adhering to the collagen. In the interstices of the platelet aggregate, plasma is caught. Activated clotting factors will not be washed away by the blood flowing by. The 
concentration of factor $\mathrm{V}$ in the crevices of the platelet plug will also be high, because it is released by the platelets. This will increase the local concentration of factor $\mathrm{V}$, that in plasma is significantly lower than that of factor $\mathrm{Xa}$ ( 25 and $200 \mathrm{nM}$ ). The conditions are therefore perfectly suited to optimize thrombin generation: plenty of procoagulant phospholipid and of clotting factors.

The question of the origin of the first traces of activated clotting factor (Xa or thrombin) remains unsolved, however. We will discuss it in more detail below.

\section{Activation of Factors $V$ and VIII}

Factors V and VIII in the form in which they circulate in the plasma are incapable of serving as a paraenzyme in the clotting mechanism. They have to undergo limited proteolysis first. Thrombin is a very efficient enzyme here. Again the question remains where the first traces of factor V (VIII) activator come from. It is sure that factor Xa can serve this function $[11,12]$, but it has also been shown that in plasma it hardly does [13]. When thrombin inactivation is enhanced, e.g. by the presence of heparin, the activation of factor VIII is retarded, which shows up as a prolongation of the APTT [for a discussion of the effects of heparin also see ref. 14]. The question of why the retardation of the activation of factor $\mathrm{V}$ does not show in a prolongation of the PT remains unsolved. In fact, the precise course of events during the prephase of thrombin formation (the lag phase) remains an enigma and requires thorough further investigation. One of the reasons for the observed difference between factors V and VIII possibly may be the fact that factor VIII circulates in a tight complex with Von Willebrand factor (VWF). The factor VIII activator, whatever it may be, therefore has to present itself in the fluid phase of the plasma in order to proteolyse the factor VIII that is attached to the VWF. After this proteolysis, factor VIIIa shows an affinity for procoagulant phospholipid rather than for VWF. Factor V, that has no plasma carrier, may possibly present itself at the phospholipid surface even before its activation and phospholipid bound activators like factor $\mathrm{Xa}$ or meizothrombin may attack it. Anyhow, thrombin (resp. factor $\mathrm{Xa}$ ) formation appears to be critically dependent upon the presence of factor $\mathrm{Va}$ (resp. factor VIIIa) and the activation of factor V (resp. factor VIII) is critically dependent upon the presence of thrombin. The physiological mechanism that breaks this stalemate position remains to be found.

\section{Thrombin-Dependent Negative Feedbacks}

On normal endothelium one finds the membrane (glyco)protein thrombomodulin, which has a high affinity for thrombin. Thrombin adsorbed to thrombomodulin converts protein $C$ into activated protein $\mathrm{C}$ $(A P C)$. APC attacks phospholipid-bound factor Va and factor VIIIa and destroys its activity by proteolytic action. The cofactor thus can no longer serve its helper function [15] (fig. 5). By this mechanism, thrombin inhibits its own formation. Again, as with factor $\mathrm{Xa}$, the active enzyme first enhances and later inhibits its own formation. Compared to the situation with factor $\mathrm{Xa}$, however, the number of reactions in the inhibitory pathway is longer. Also here the presence of intact endothelium downstream of the thrombin source is necessary. This may lead to the speculation that this mechanism is primarily suitable for the prevention of the 


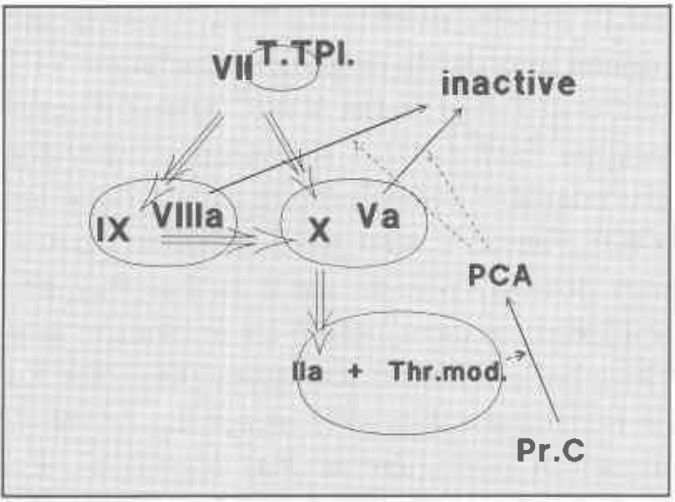

Fig. 5. The negative feedback of thrombin via activated protein $\mathrm{C}$.

extension of the thrombotic process to unaffected parts of the vascular bed, downstream of the lesion.

\section{Continuous Extravascular Coagulation?}

The proenzymes of blood coagulation are comparatively small molecules $(<70,000)$. The paraenzymes are of a much higher molecular weight $(>300,000)$. This makes that under normal circumstances the proenzymes may appear in the extravascular fluid whereas the paraenzymes will not. The phospholipids are present in the blood platelets which will not normally leave the vascular bed either. This opens the interesting possibility that at the sites where thromboplastin is present, i.e. in a layer of perivascular cells, factor VII is activated and that this factor, at a very low pace, may activate some factor $X$. This mechanism may produce low concentrations of thrombin near the cells that carry thromboplastin at their surface. As soon as there is a breach in a blood vessel the paraenzymes will appear, will be activated by the thrombin present, and speed up the process tremendously. Also the platelets arrive, adhere to the interstitial material of the connective tissue, flip-flop readily because of the thrombin already present and form a locus of high thrombogenic activity.

Anyhow, this is necessarily only part of the story, because blood drawn under circumstances that practically exclude contact with tissue still develops thrombin.

\section{Nonlinearity and Flow Phenomena}

Enzyme systems in which the quasi stationary rate of a key reaction depends upon an enzyme or substrate concentration in an S-shaped, hysteresis type of function, are called nonlinear (fig. 6). This type of response accounts for a number of properties that are commonly found in biological systems, such as thresholds, i.e. sudden changes of output at a given level of input; memory, i.e. behavior dependent upon the previous history; morphogenesis i.e. the formation of spatial structures. These phenomena are observed only at a certain degree of complexity of the enzyme system. Sel'kov [16] investigated the minimal requirements of complexity for nonlinearity to occur. One of his models is depicted in figure 7 . It is immediately evident that this general mechanism applies to thrombin formation. It may therefore be expected that, e.g., threshold phenomena are observed. This may be the background to the common observation that thrombosis occurs explosively when a thrombogenic threshold is passed and that it can be prevented by increasing this threshold via inhibition of the thrombin-generating mechanism, i.e. by oral anticoagulation or by heparin administration. In simulation 


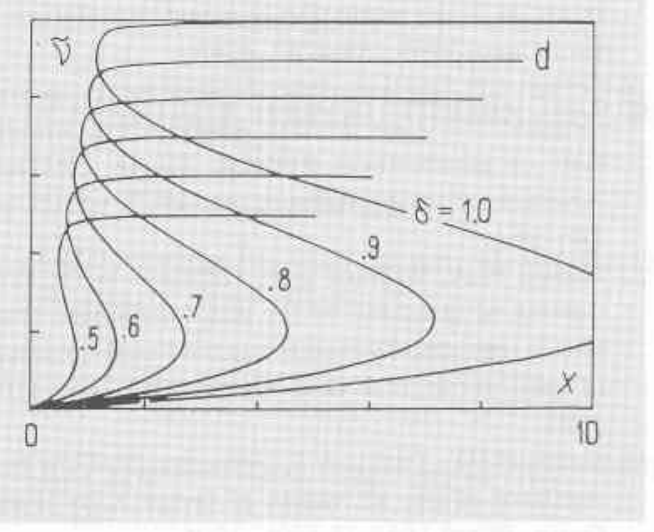

6

experiments it is indeed observed that below a critical limit of factor $\mathrm{Xa}$ thrombin generation will not ensue, whereas above that limit it is explosive [6].

It appears that no realistic picture of the reaction mechanism of thrombin formation can be sketched without taking positive and negative feedback reactions into account.

This may be a necessary level of complication, it is by no means sufficient. As already hinted at above, it is impossible to obtain a picture of thrombin generation that approaches reality without taking into account that in (patho)-physiology the generation of thrombin is not a merely chemical process but linked to the appearance of macroscopic procoagulant surfaces. Recent research made it clear that such surfaces offer conditions that differ essentially from those in a test tube where the phospholipids are present as a suspension of vesicles [17]. This indicates that, in order to obtain a realistic picture of thrombin generation under physiological and pathological conditions, one has to study it in the presence of macroscopic surfaces and under flow conditions. The ele-

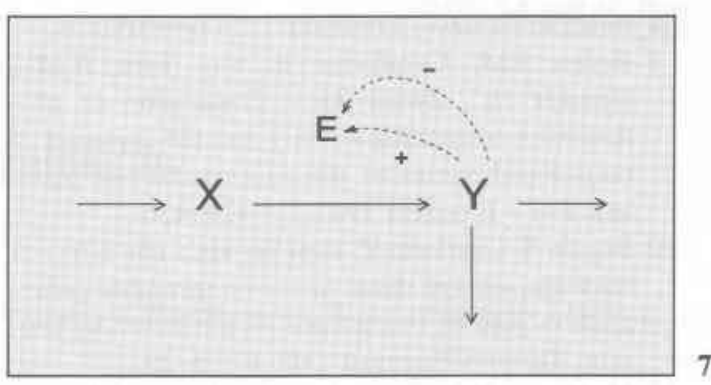

Fig. 6. Nonlinear relation between substrate concentration and reaction velocity (from ref. 16].

Fig. 7. One of the nonlinear mechanisms of Sel'kov. [from ref. 16].

gant experiments started by Gemmel et al. [18] may be at the basis of a new development here.

\section{References}

1 Béguin S, Lindhout T, Hemker HC: The mode of action of heparin in plasma. Thromb Haemost 1988;60:457-462.

2 Pekelharing CA: Untersuchungen über das Fibrinferment. Verh K Akad Wet, Sect 2/1 1893;3: 3-52.

3 Macfarlane RG: A cascade mechanism for blood coagulation. Nature 1964;202:498-499.

4 Davie EW, Ratnoff OD: Waterfall sequence for intrinsic blood clotting. Science 1964;145:13101312.

5 Jesty J: Interaction of feedback control and product inhibition in the activation of factor $\mathrm{X}$ by factor IXa and VIII. Haemostasis 1991;21:208*218.

6 Willems GM, Lindhout T, Hermens WTh, Hemker HC: Simulation model for thrombin generation in plasma. Haemostasis 1991;21:197207.

7 Sandset PM, Abildgaard U: Extrinsic pathway inhibitor - The key to feedback control of blood coagulation initiated by tissue thromboplastin. Haemostasis 1991;21:219-239. 
8 Bendetowicz AV, Lindhout T: in preparation.

9 Bevers EM, Comfurius P, van Rijn JLML, Hemker HC, Zwaal RFA: Generation of prothrombin-converting activity and the exposure of phosphatidylserine at the outer surface of platelets. Eur J Biochem 1982;122:429-436.

10 Béguin S, Lindhout T, Hemker HC: The effect of trace amounts of tissue factor on thrombin generation in platelet rich plasma its inhibition by heparin. Thromb Haemost 1989;61:25-29.

11 Monkovic DD, Tracy PB: Activation of human factor $\mathrm{V}$ by factor $\mathrm{Xa}$ and thrombin. Biochemistry 1990;29:1118-1128.

12 Lollar P, Knutson GJ, Fass DN: Activation of porcine factor VIII: $\mathrm{C}$ by thrombin and factor $\mathrm{Xa}$. Biochemistry 1985;24:8056.

13 Pieters J, Lindhout T, Hemker HC: In situ-generated thrombin is the only enzyme that effectively activates factor VIII and factor V in thromboplastin-activated plasma. Blood 1989;74:1021-1024.

14 Ofosu FA: Modulation of the enzymatic activity of $\alpha$-thrombin by polyanions: Consequences on intrinsic activation of factor $\mathrm{V}$ and factor VIII. Haemostasis 1991;21:240-247.
15 Esmon CT: The roles of protein and thrombomodulin in the regulation of blood coagulation. $\mathrm{J}$ Biol Chem 1989;264:4743-4746.

16 Sel'kov EE: Nonlinearity of multienzyme systems; Hemker HC, Hess B (eds): Analysis and Simulation of Biochemical Systems. North Holland/ American Elsevier, Amsterdam, 1972, vol 25, pp 145-162.

17 Giesen PLA, Willems GM, Hermens WTh: Production of thrombin by the prothrombinase complex is regulated by membrane mediated transport of prothrombin. J Biol Chem 1991;266:1379_ 1382.

18 Gemmel HL, Turitto VT, Nemerson Y: Flow as a regulator of the activation of factor $\mathrm{X}$ by tissue factor. Blood 1988;72:1404-1406.

Prof. Dr. H.C. Hemker

Biomedisch Centrum

Beeldsnijdersdreef 101

NL-6200 MD Maastrict (The Netherlands) 